\title{
Bronchial challenge of normal subjects with the endotoxin of Enterobacter agglomerans isolated from cotton dust
}

\author{
J P JAMISON AND R C LOWRY
}

From the Respiratory Investigation Centre, Belfast City Hospital, and Department of Physiology, The Queen's University of Belfast, Belfast, UK

ABSTRACT Endotoxin produced by a culture of Enterobacter agglomerans isolated from cotton dust was inhaled by 12 normal subjects. No significant airway constriction was obtained in doses equivalent to those experienced in a workshift in a dusty mill. There was a statistically significant difference between this result and the bronchoconstriction that had occurred after flax dust inhalation in the same subjects. It is suggested that Enterobacter agglomerans endotoxin is not the causative agent of the acute bronchoconstriction that follows inhalation of textile dust.

Neal et al reported that inhalation of a sterile filtrate of a culture of Aerobacter cloacae by a volunteer resulted in fever, dyspnoea, and coughing. ${ }^{1}$ Pernis et al administered the endotoxin of Escherichia coli to three subjects and the endotoxin of Salmonella abortus equi to two of these subjects in doses of 15,30 , and $60 \mu$. $^{2}$ Coughing, slight dyspnoea, and slight reduction in forced expiratory volume in one second $\left(\mathrm{FEV}_{1}\right)$ were reported along with fever, malaise, and a skin reaction. Cavagna et al found that two out of eight normal subjects inhaling $80 \mu \mathrm{g}$ of $E$ coli endotoxin showed a fall in FEV of more than $10 \% .{ }^{3}$ Van der Zwan et al found a $14 \%$ fall in $\mathrm{FEV}_{1}$ in subjects with bronchial hyperreactivity after inhaling $4 \mathrm{mg}$ endotoxin from Haemophilis influenza. ${ }^{4}$

These experiments suggested that the bacterial endotoxin content of textile dusts may be the causative agent of the bronchoconstriction that is the response of normal subjects to these dusts. The effects were, however, not easily comparable with the equivalent dose of endotoxin in textile dusts. A further uncertainty is the evidence that endotoxins from different bacteria have differing biological activities. $^{5-7}$

We have reported the ventilatory responses of a panel of 12 normal subjects to flax dust when we found a $30 \%$ reduction in this response after steam treatment which also reduced the endotoxin content by $50 \% .^{8}$ It is therefore of interest to compare the response of this panel of subjects with the direct inhalation of the appropriate endotoxin in the equivalent dose. Cotton and other organic dusts commonly contain Enterobacter agglomerans ${ }^{9}$ and this has also been found in flax dust (B Buick, personal communication). We have challenged our panel of normal subjects with the endotoxin produced by this organism, isolated and purified by the technique of Helander et al, ${ }^{6}$ and given in a dose guided by Limulus assay of the endotoxin content of flax dust.

\section{Methods}

\section{SUBJECTS}

The same panel of 12 normal subjects who participated in the flax dust trial ${ }^{8}$ were studied. One subject was a smoker but did not smoke on trial days. The subjects gave informed consent and the experiments had the approval of the ethical committee.

\section{ENDOTOXIN}

The endotoxin was prepared in Helsinki by Helander et al. ${ }^{6}$ The organism Ent agglomerans was isolated and cultured from the cotton dust and the lipopolysaccharide extract prepared from the culture. The endotoxin was dissolved in $2 \mathrm{ml}$ of saline and inhaled by ultrasonic nebuliser (Pulmasonic) over a period of 15 minutes. 


\section{PROTOCOL}

A crossover trial was carried out on the 12 normal subjects randomly divided into two groups of six subjects in each group; one group received $5 \mu \mathrm{g}$ of endotoxin first followed in two weeks by saline whereas the other group received the saline first and then the endotoxin. A further trial was carried out using the higher dose of $12 \mu \mathrm{g}$. The subjects and the observer of lung function were unaware whether a saline control or endotoxin challenge was being administered. Three forced expiratory manoeuvres were recorded by a McDermott computerised spirometer and flow/ volume curves constructed. These measurements were carried out immediately before and at one hour and four hours after the start of the bronchial challenge. Single breath carbon monoxide transfer factor was measured before and after the high dose of endotoxin using P K Morgan gas transfer equipment. This measurement was made on one group of six subjects.

\section{ENDOTOXIN ASSAY OF FLAX DUST}

The level of endotoxin in the flax dust was measured by a modified Limulus method (Rylander and Morey ${ }^{10}$ ). The dust analysed was that used in the previous report on the effects of inhaled flax dust on these subjects. ${ }^{8}$

\section{STATISTICAL ANALYSES}

Analysis of variance was used to compare mean expiratory volumes and flow rates after saline and after $5 \mu \mathrm{g}$ endotoxin and to compare the means before and after $12 \mu \mathrm{g}$ endotoxin. Analysis of variance was also used to compare the decreases after $12 \mu \mathrm{g}$ endotoxin with the decreases after untreated flax dust found in the previous trial. ${ }^{8}$ A paired $t$ test was used to compare the mean transfer factor before and after $12 \mu \mathrm{g}$ of endotoxin.

\section{Results}

\section{BRONCHIAL CHALLENGE}

Forced expirations

The means of the three forced expirations in all 12 subjects before and after saline and endotoxin are shown in tables 1 and 2 . The prechallenge means differed little, whether before saline or endotoxin, and these means were also similar to the control means obtained on these same 12 subjects in the trial of flax dust inhalation. ${ }^{8}$ After challenge with saline there were small increases at one hour in mean $\mathrm{FEV}_{1}, \mathrm{FVC}$, and forced mid-expiratory flow rate $\left(\mathrm{MEF}_{\mathrm{so}}\right)$ and at four hours either no change or small decreases.

After $5 \mu \mathrm{g}$ endotoxin there were small decreases at both times, the largest decrease being 0.1291 in FVC at four hours. All $p$ values comparing the means before and after saline and $5 \mu \mathrm{g}$ endotoxin were greater than $\mathbf{0} \cdot 22$.

After $12 \mu \mathrm{g}$ endotoxin (table 2) the changes in expiratory volumes showed slightly larger decreases at one hour and slightly smaller decreases at four hours, compared with the $5 \mu \mathrm{g}$ dose. The midexpiratory flows showed a smaller decrease at one hour and a slight increase at four hours. None of the postchallenge means was statistically significantly different from the prechallenge means, the smallest $p$ value being greater than 0.18 for the FVC at one hour.

\section{Gas transfer}

The mean transfer factor fell from 12.18 to 10.8 $\mathrm{mmol} / \mathrm{min} / \mathrm{kPa}$ at four hours. There was no significant difference between the mean transfer factor at one hour and control, but the mean at four hours was significantly lower than control $(p<0.02)$. There was no significant change in mean alveolar volume, 6.41 before and 6.2 1 after four hours ( $p>0.3)$. The transfer coefficient decreased significantly from 1.93 before to $1.75 \mathrm{mmol} / \mathrm{min} / \mathrm{kPa} / \mathrm{l}$ at four hours $(\mathrm{p}<0.01)$.

\section{Symptoms}

One subject only (No 5) reported chest tightness after the higher dose of endotoxin. No fever, chills, malaise, or other symptom occurred in any subject.

Comparison with previously reported effects of dust When the largest decreases after the high dose of

Table 1 Mean volumes ( $l$ ) and mid-expiratory flow rates ( $l / s)$ before challenge and at one hour and four hours after saline and $5 \mu \mathrm{g}$ endotoxin in the double blind crossover trial. $p$ Values compare the saline and endotoxin challenges on the 12 subjects (three forced expiratory manoeuvres on each occasion)

\begin{tabular}{|c|c|c|c|c|c|c|c|c|c|}
\hline & \multicolumn{3}{|l|}{$F E V_{1}$} & \multicolumn{3}{|l|}{$F V C$} & \multicolumn{3}{|l|}{$M E F_{\text {so }}$} \\
\hline & Before & $I h$ & $4 h$ & Before & $1 h$ & $4 h$ & Before & $1 \mathrm{~h}$ & $4 b$ \\
\hline $\begin{array}{l}\text { Saline } \\
\text { Endotoxin } \\
\text { p > }\end{array}$ & $\begin{array}{l}3.940 \\
3.963 \\
0.62\end{array}$ & $\begin{array}{l}4.002 \\
3.939 \\
0.56\end{array}$ & $\begin{array}{l}3.944 \\
3.915 \\
0.57\end{array}$ & $\begin{array}{l}5.406 \\
5.416 \\
0.92\end{array}$ & $\begin{array}{l}5.418 \\
5 \cdot 365 \\
0.59\end{array}$ & $\begin{array}{l}5 \cdot 359 \\
5 \cdot 287 \\
0 \cdot 22\end{array}$ & $\begin{array}{l}3.869 \\
3.940 \\
0.55\end{array}$ & $\begin{array}{l}3.998 \\
3.898 \\
0.25\end{array}$ & $\begin{array}{l}3.848 \\
3.922 \\
0.50\end{array}$ \\
\hline
\end{tabular}


Table 2 Mean (SEM) volumes ( $l$ ), flow rates ( $l / s)$ and transfer factors (mmol/min $k P a)$ before and at one hour and four hours after $12 \mu \mathrm{g}$ endotoxin. Means are of three forced expirations by the 12 subjects and single determinations of transfer factor on six subjects. $p$ Values comparing before and after means are given in parentheses beside the corresponding means after endotoxin

\begin{tabular}{lllll}
\hline & $F E V_{1}$ & $F V C$ & $M E F_{50}$ & $T L$ \\
\hline Before & $3.943(0.093)$ & $5.378(0.116)$ & $3.792(0.149)$ & $12.18(0.79)$ \\
After 1 hour & $3.874(>0.19)$ & $5.302(>0.18)$ & $3.774(>0.84)$ & $11.3(>0.10)$ \\
After 4 hours & $3.922(>0.60)$ & $5.341(>0.50)$ & $3.851(>0.50)$ & $10.8(<0.02)$ \\
\hline
\end{tabular}

endotoxin, recorded at one hour, were compared with the decreases after inhaling flax dust for six hours there were statistically significantly smaller decreases with the present endotoxin challenge in $\operatorname{FEV}_{1}(\mathrm{p}<$ $0.03)$, FVC $(p<0.05)$, and $\mathrm{MEF}_{50}(\mathrm{p}<0.02)$.

ENDOTOXIN LEVELS IN FLAX DUST

The two batches of untreated flax dust prepared for the two dust trials ${ }^{8}$ contained means (SEM, $n=6$ analyses) of 111 (19) $\mu \mathrm{g}$ of endotoxin per gram of dust and $100(17) \mu \mathrm{g} / \mathrm{g}$ for the second batch. The statistically significantly lower values $(p<0.05)$ of 16 (4) and 51 (9) $\mu \mathrm{g} / \mathrm{g}$ were obtained for the dusts from the equivalent flax which had been steamed.

\section{Discussion}

\section{BACTERIA AND ENDOTOXIN SOURCE}

The Ent agglomerans endotoxin used in this study was chosen as the most likely causative agent of the acute bronchoconstriction previously described when our panel of subjects inhaled flax dust. ${ }^{8}$ Large counts of Enterobacter have been reported in cotton and other organic dusts, ${ }^{9}$ and this organism has been found to be particularly effective in mobilising leucocytes to the lungs of guinea pigs. ${ }^{611}$ Tuffnell suggested that the commonest organisms in these dusts were of the genus Bacillus ${ }^{12}$ and he found occasional responses to their inhalation. ${ }^{13}$ Nevertheless, no leucocyte response to Bacillus was found by Rylander and Lundholm. ${ }^{11}$

\section{DOSE OF ENDOTOXIN}

The dose of endotoxin used was chosen to be comparable with that given in the dust challenge experiments reported previously or in a working shift in a dusty mill. Assuming a resting ventilation rate of $7 \mathrm{l} / \mathrm{min}$, respiration in an atmosphere containing $5 \mathrm{mg}$ dust $/ \mathrm{m}^{3}$ with $100 \mu \mathrm{g}$ endotoxin/g of dust for six hours would be a total inhalation of $1.26 \mu \mathrm{g}$. Higher ventilation rates would occur in exercise. Cavagna et al estimated the endotoxin content of cotton dust by comparison with the dose of purified $E$ coli endotoxin that produced skin necrosis in rabbits. ${ }^{3}$ They found $1.4 \mathrm{mg} / \mathrm{g}$ of dust, which would be equivalent to a dose of $17.6 \mu \mathrm{g}$ assuming a ventilation rate of $7 \mathrm{l} / \mathrm{min}$ as above. Cinkotai et al found variable endotoxin concentrations from 0.2 to $1.6 \mathrm{mg} / \mathrm{g}$ cotton dust. ${ }^{14}$ Pernis et al found 0.15 to $0.5 \mathrm{mg} / \mathrm{g}$ of cotton by a pyrogenic assay, ${ }^{2}$ although up to $10 \mathrm{mg} / \mathrm{g}$ of material was extracted. $^{2}$ Antweiler calculated that a content of $0.5 \mathrm{mg} / \mathrm{g}$ of cotton card room dust is more than the maximum possible. ${ }^{15}$ The Limulus assay is thought to be both sensitive and specific for endotoxin. ${ }^{16}$ Using this assay, Rylander and Morey quote airborne concentrations of 0.5 to $2.5 \mu \mathrm{g} / \mathrm{m}^{3} .^{10}$ The equivalent calculation would give a dose range of 1.26 to $6.3 \mu \mathrm{g}$. These comparisons are subject to various assumptions and uncertainties associated with the techniques of estimating endotoxin concentrations, but the doses of $5 \mu \mathrm{g}$ and $12 \mu \mathrm{g}$ do appear to be comparable with the doses to which our panel of subjects were exposed during dust inhalation.

The duration of exposure in the endotoxin challenge experiments was necessarily much shorter than with dust inhalation. This means that to administer the same total dose the airways are being exposed to a correspondingly higher concentration of endotoxin.

A further difference between the dust and endotoxin challenge is that the liquid droplets from the nebuliser may be distributed differently in the airways than dust particles. With the wide size ranges for both droplets and dust particles probably neither large nor small airways were unexposed to either material. The manufacturers of the nebuliser, DeVilbiss Health Care UK Ltd, quote the mass median diameter of the liquid droplets as $2.5 \mu \mathrm{m}$ which is smaller and therefore more likely to enter the lung than the dust particles in our previous trials whose mass median diameter was $4.5 \mu \mathrm{m}$.

\section{TIME OF MEASUREMENTS}

A bronchoconstrictor response at times other than one hour or four hours after the inhalation of endotoxin cannot be excluded but against this possibility is the lack of symptoms except in one subject, a smoker who showed constriction at both times of recording. Neal et al found responses about $\mathbf{4 5}$ minutes after inhalation. ${ }^{1}$ Cavagna et al found a maximal effect after endotoxin inhalation at $\mathbf{3 0}$ minutes to one hour, and lasting six hours. ${ }^{3}$ Pernis et al found that responses in animals appeared 30-50 minutes after 
the end of 15 minutes of endotoxin inhalation. ${ }^{2}$ Buck and Bouhuys found a maximal bronchoconstriction at 90-120 minutes after a cotton extract aerosol was inhaled. ${ }^{17}$ Van der Zwan reported a bronchoconstrictor response maximal at half hour and lasting four hours after inhaling endotoxin. ${ }^{4}$ The time delays for these responses suggest that the measurements made at one hour and four hours in the present study should have detected any response to the endotoxin inhalation. Such delays in responses are also the most relevant to byssinosis. ${ }^{18}$

\section{PHYSIOLOGICAL RESPONSES}

There was an $11 \%$ decrease in transfer factor after four hours. This measurement was made on six subjects, randomly selected, and the difference was statistically significant. It could not be explained by a decrease in alveolar volume, nor by bronchoconstriction. Inhalation of cotton dust has been reported to cause no change in transfer factor, ${ }^{1920}$ although some suggestion of impaired ventilation/perfusion ratios has been made by the finding of a fall in the arterial partial pressure of oxygen after exposure of mill workers to hemp dust. ${ }^{21}$ Merchant et al also reported some fall in arterial oxygen pressure after cotton dust but the mean fall was small and not significant. ${ }^{22}$ Muittari et al reported a decrease in transfer factor at four hours after inhaling $0.8-4 \mu \mathrm{g}$ endotoxin in a study of bath water fever. ${ }^{23}$ There is therefore some suggestion that endotoxins may cause impairment of gas transfer but this is not a typical acute reaction to textile dust.

A relation of endotoxin to mill fever is not necessarily excluded by the lack of appearance of symptoms suggestive of this condition in this study. This was also the finding of Cavagna et al, ${ }^{3}$ though pyrexia was found in the inhalation studies of Pernis et al. ${ }^{2}$ Tolerance to the pyrogenic effect of endotoxin devel- ops with repeated exposure and this tolerance may
last up to five weeks. ${ }^{24}$ The limited but definite exposure of our subjects to flax dust as managers in flax mills might account for their development of tol- $\overrightarrow{\vec{P}}$ erance.

\section{Airways}

Only one of our subjects (No 5) showed any appreciable fall in ventilatory lung function after $12 \mu \mathrm{g}$ of $\stackrel{\circ}{\circ}$ endotoxin and this fall was larger than he experienced is with flax dust inhalation. Possibly the histamine $\overrightarrow{0}$ releasing property of endotoxin ${ }^{2}$ accounted for this prolonged bronchoconstriction, particularly if this $\vec{\omega}$ subject had bronchial hyperreactivity to histamine. ${ }^{4}$ His reaction, however, may have been due to some other factor as the amount of histamine released by endotoxin was found to be insignificant by Antweiler. ${ }^{15}$

Whereas previous work has suggested a causative association between endotoxin and byssinosis, the $ᄋ$ results of inhalation tests have had less specific effects, not easily extrapolated to the disease. The lack of $\bar{z}$ significant change in the mean ventilatory lung function tests of this group of subjects is not likely to be $\overrightarrow{0}$ easily consistent with endotoxin being the causative agent of the bronchoconstriction which this group has previously shown to acute textile dust inhalation, although an interactive role with other agents has not been excluded.

We thank Professor R Rylander, University of Gothenberg, who supplied the endotoxin, assayed the $\overline{0}$ levels in flax dust, and provided financial support. We also thank Mr B Buick for his technical help.

Requests for reprints to: Dr J P Jamison, Department of Physiology, Medical Biology Centre, 97 Lisburn Road, Belfast, Northern Ireland.

Appendix A

Mean individual changes after $5 \mu \mathrm{g}$ endotoxin (decreases negative) in expiratory volumes (l) and mid-expiratory flow rate $(l / s)$, three forced expiratory manoeuvres per subject

\begin{tabular}{|c|c|c|c|c|c|c|}
\hline \multirow[t]{2}{*}{ Subject No } & \multicolumn{2}{|l|}{$F E V_{1}$} & \multicolumn{2}{|l|}{$F V C$} & \multicolumn{2}{|l|}{$M E F_{\mathrm{so}}$} \\
\hline & $l h$ & $4 h$ & $1 h$ & $4 h$ & $I h$ & $4 h$ \\
\hline $\begin{array}{r}1 \\
2 \\
3 \\
4 \\
5 \\
6 \\
7 \\
8 \\
9 \\
10 \\
11 \\
12\end{array}$ & $\begin{array}{l}+0.030 \\
+0.050 \\
+0.337 \\
+0.137 \\
-0.260 \\
-0.083 \\
-0.354 \\
+0.016 \\
+0.067 \\
-0.247 \\
-0.054 \\
+0.077\end{array}$ & $\begin{array}{l}+0.154 \\
-0.023 \\
+0.090 \\
+0.107 \\
-0.210 \\
-0.077 \\
-0.500 \\
+0.036 \\
+0.087 \\
-0.070 \\
-0.017 \\
-0.150\end{array}$ & $\begin{array}{r}-0.100 \\
+0.067 \\
+0.280 \\
+0.107 \\
-0.307 \\
-0.097 \\
-0.330 \\
-0.160 \\
+0.080 \\
-0.060 \\
-0.173 \\
+0.083\end{array}$ & $\begin{array}{l}+0.137 \\
+0.067 \\
+0.183 \\
+0.100 \\
-0.330 \\
-0.130 \\
-0.517 \\
-0.130 \\
-0.063 \\
-0.093 \\
-0.550 \\
-0.217\end{array}$ & $\begin{array}{l}-0.150 \\
-0.053 \\
+0.390 \\
+0.586 \\
-0.174 \\
-0.275 \\
-0.483 \\
+0.066 \\
+0.020 \\
-0.483 \\
-0.180 \\
+0.230\end{array}$ & $\begin{array}{l}-0.354 \\
-0.246 \\
-0.257 \\
+0.500 \\
-0.034 \\
-0.150 \\
-0.567 \\
+0.013 \\
+0.470 \\
+0.232 \\
-0.150 \\
+0.326\end{array}$ \\
\hline
\end{tabular}


Appendix B

Mean individual changes after $12 \mu \mathrm{g}$ endotoxin (decreases negative) in expiratory volumes (l) and mid-expiratory flow rate $(l / s)$, three forced expiratory manoeuvres per subject, and transfer factor ( $\mathrm{mmol} / \mathrm{kPa} / \mathrm{min})$

\begin{tabular}{|c|c|c|c|c|c|c|c|c|}
\hline \multirow[t]{2}{*}{ Subject No } & \multicolumn{2}{|l|}{$F E V_{1}$} & \multicolumn{2}{|l|}{$F V C$} & \multicolumn{2}{|l|}{$M E F_{50}$} & \multicolumn{2}{|l|}{$T L$} \\
\hline & $l h$ & $4 h$ & $I h$ & $4 h$ & $l h$ & $4 h$ & $1 \mathrm{~h}$ & $4 h$ \\
\hline $\begin{array}{r}1 \\
2 \\
3 \\
4 \\
5 \\
6 \\
7 \\
8 \\
9 \\
10 \\
11 \\
12\end{array}$ & $\begin{array}{r}-0.063 \\
-0.047 \\
+0.030 \\
-0.192 \\
-0.543 \\
-0.040 \\
+0.025 \\
+0.063 \\
-0.173 \\
-0.037 \\
+0.013 \\
+0.133\end{array}$ & $\begin{array}{l}+0.067 \\
+0.117 \\
+0.037 \\
+0.110 \\
-0.390 \\
-0.040 \\
+0.002 \\
-0.027 \\
-0.100 \\
-0.037 \\
-0.060 \\
+0.067\end{array}$ & $\begin{array}{r}-0.113 \\
0.000 \\
+0.070 \\
-0.065 \\
-0.557 \\
-0.070 \\
-0.140 \\
-0.100 \\
-0.143 \\
-0.063 \\
-0.007 \\
+0.270\end{array}$ & $\begin{array}{r}+0.037 \\
+0.090 \\
+0.087 \\
+0.117 \\
-0.543 \\
-0.053 \\
-0.047 \\
-0.097 \\
-0.087 \\
-0.017 \\
-0.033 \\
+0.107\end{array}$ & $\begin{array}{l}+0.080 \\
-0.113 \\
+0.007 \\
-0.325 \\
-0.783 \\
+0.500 \\
+0.140 \\
+0.263 \\
+0.190 \\
-0.077 \\
+0.013 \\
-0.107\end{array}$ & $\begin{array}{l}+0.380 \\
+0.097 \\
-0.010 \\
+0.507 \\
-0.377 \\
+0.550 \\
-0.107 \\
-0.173 \\
-0.027 \\
-0.165 \\
-0.050 \\
+0.080\end{array}$ & $\begin{array}{l}+0.2 \\
+0.3 \\
-2.3 \\
-0.1 \\
-1.2\end{array}$ & $\begin{array}{l}+0.3 \\
-2.5 \\
-1.7 \\
-1.3 \\
-1.4\end{array}$ \\
\hline
\end{tabular}

\section{References}

${ }^{1}$ Neal PA, Schneiter R, Caminita BH. Report on acute illness among rural mattress makers using low grade, stained cotton. JAMA 1942;119:1074-82.

${ }^{2}$ Pernis B, Vigliani EC, Cavagna C, Finulli M. The role of bacterial endotoxins in occupational diseases caused by inhaling vegetable dusts. Br J Ind Med 1961;18:120-9.

${ }^{3}$ Cavagna G, Foa V, Vigliani EC. Effects in man and rabbits of inhalation of cotton dust or extracts and purified endotoxins. $\mathrm{Br}$ $J$ Ind Med 1969;26:314-21.

4 Van der Zwan JC, Orie NGM, Kauffman HF, Wiers PWJ, de Vries K. Bronchial obstructive reactions after inhalation with endotoxin and precipitinogens of haemophilus influenzae in patients with chronic non-specific lung disease. Clin Allergy 1982;12:547-59.

${ }^{5}$ Luderitz O, Galanos C, Lehmann V, Mayer H, Rietschel ET, Weckesser J. Chemical structure and biological activities of lipid As from various bacterial families. Naturwissenschaften 1978;65:578-85.

${ }^{6}$ Helander I, Salkinoja-Salonen M, Rylander R. Chemical structure and inhalation toxicity of lipopolysaccharides from bacteria on cotton. Infect Immun 1980;29:859-62.

${ }^{7}$ Etzel KR, Swerdel MR, Swerdel JN, Cousins RJ. Endotoxin induced changes in copper and zinc metabolism in the Syrian hamster. J Nutr 1982;112:2363-73.

8 Jamison JP, Langlands JHM, Bodel C. Ventilatory responses of normal subjects to flax dust inhalation: the protective effect of autoclaving the flax. Br J Ind Med 1985;42:196-201.

${ }^{9}$ Rylander R, Nordstand A, Snella MC. Bacterial contamination of organic dusts; effects on pulmonary cell reactions. Arch Environ Health 1975;30:137-40.

${ }^{10}$ Rylander R, Morey P. Airborne endotoxin in industries processing vegetable fibres. Am Ind Hyg Assoc J 1982;43:811-2.

${ }^{11}$ Rylander R, Lundholm M. Bacterial contamination of cotton and cotton dust and effects on the lungs. Br $J$ Ind Med 1978;35:204-7.

12 Tuffnell $P$. The relationship of byssinosis to the bacteria and fungi in the air of textile mills. $B r J$ Ind Med 1960;17:304-6.

13 Tuffnell P. Experimental byssinosis. Br J Ind Med 1960;17:307-9.

${ }^{14}$ Cinkotai FF, Lockwood MG, Rylander R. Airborne microorganisms and prevalence of byssinotic symptoms in cotton mills. Am Ind Hyg Assoc J 1977;38:554-9.

${ }^{15}$ Antweiler H. Histamine liberation by cotton dust extracts: evidence against its causation by bacterial endotoxins. $\mathrm{Br} J$ Ind Med 1961;18:130-2.

${ }^{16}$ Wildfeuer A, Heymer B, Schleifer KH, Haferkamp O. Investigations on the specificity of the Limulus test for the detection of endotoxin. Appl Microbiol 1974;28:867-71.

${ }^{17}$ Buck MG, Bouhuys A. Byssinosis: airway constrictor responses to cotton bracts. Lung 1980;158:25-32.

${ }^{18}$ Schilling RSF. Byssinosis in the British cotton textile industry. $\mathrm{Br}$ Med Bull 1950;7:52-6.

${ }^{19}$ Edwards J, McCarthy P, McDermott M, Nicholls PJ, Skidmore JW. The acute physiological, pharmacological and immunological effects of inhaled cotton dust in normal subjects. $J$ Physiol 1970;208:63-64P.

${ }^{20}$ Zuskin E, Valic F, Bouhuys A. Byssinosis and airway responses due to exposure to textile dust. Lung 1976;154:17-24.

${ }^{21}$ Merino VL, Lombart RL, Marco RF, Carnicero AB, Guillen FG, Bouhuys A. Arterial blood gas tensions and lung function during acute responses to hemp dust. Am Rev Respir Dis 1973;107:809-15.

${ }^{22}$ Merchant JA, Halprin GM, Hudson AR, et al. Evaluation before and after exposure-the pattern of physiological response to cotton dust. Ann NY Acad Sci 1974;221:38-43.

${ }^{23}$ Muittari A, Rylander R, Salkinoja-Salonen M. Endotoxin and bath water fever. Lancet 1980;ii:89.

${ }^{24}$ Greisman SE, Hornick RB. Mechanisms of endotoxin tolerance with special reference to man. J Infect Dis 1973;128:S265-76. 